차광도포제 처리에 의한 포도 비가림 시설 하부 온도의 변화

\author{
정성민 $^{1 *} \cdot$ 허윤영 ${ }^{2} \cdot$ 임동준 $^{2} \cdot$ 정경호 $^{2}$ \\ 1국립원예특작과학원 기획조정과 \\ 2국립원예특작과학원 과수과
}

\title{
Temperature Changes under Plastic Film Rain Shelter Using Different Concentration of Shading Paint in Vineyard
}

\author{
Sung Min Jung ${ }^{1 *}$, Youn Young Hur ${ }^{2}$, Dong Jun $\mathrm{Im}^{2}$, and Kyung Ho Chung \\ ${ }^{1}$ Planning and Coordination Division, National Institute Horticultural and Herbal Science, RDA Wanju 55365, Korea \\ ${ }^{2}$ Fruit Research Division, National Institute Horticultural and Herbal Science, RDA Wanju 55365, Korea
}

\begin{abstract}
Shading paint (water-soluble) is one of the temperature control agents inside of a greenhouse in summer. Plastic film rain shelter is a unique system in Korean, prevents disease development vineyards, but it causes the heat inside a shelter in summer. Shading paint treatment with different shading rates $(15,25$, and $35 \%)$ outside of plastic rain shelter avoided excessive heat inside. Shading paint influenced sunlight under plastic rain shelter in a different manner at each treatment. 35\% of shading paint treatment reduced $45 \%$ of PPFD (Photosynthesis Photon Flux Density) than non-treatment control. Shading paint had the significance of efficiency to reduce the temperature under plastic rain shelter. $35 \%$ of shading paint treatment reduced $2^{\circ} \mathrm{C}$ of bunch temperature than non-treatment control. However, shading paint treatment had not to control lower than ambient temperature. $35 \%$ of shading paint treatment is available to prevent excessive heat damage and poor fruit quality under plastic film rain shelter in summer in Korean vineyards.
\end{abstract}

Additional key words : Heat, White water paint

\section{서 론}

지구온난화로 인해 2100년 지구의 연평균온도는 1986 2005년 대비 약 $3.7^{\circ} \mathrm{C}(\mathrm{RCP} 8.5)$ 상승할 것으로 예 측되며(IPCC, 2014), 우리나라의 년 평균기온도 이와 유 사하게 2100년에는 1981 2010년 대비 약 $3.8^{\circ} \mathrm{C}$ 상승할 것으로 예상된다 (KMA, 2018). 이와 같은 지구온난화로 인한 연평균기온 상승으로 인해 전 지구적인 국지적인 돌발 기상재해도 빈발하고 있다. 우리나라의 경우 여름 철 일 최고기온이 $33^{\circ} \mathrm{C}$ 를 넘게 되면 폭염으로 정의하며, 평년기준 연간 7.3일 발생하는 것으로 조사되나, 2018년 의 경우 대구지역의 폭염일수는 23.2일로 평년에 비해 3 배 길게 발생하였다 (KMA, 2018). 이는 여름철 장마의 급격한 세력약화로 인해 조기에 시작된 무더위와 여름 내 강수량의 부족, 강한 일조로 인한 폭염이었다. 현재 와 같은 지구온난화가 계속될 경우(RCP 8.5$)$ 기상청에

*Corresponding author: fizzfizz@korea.kr

Received June 27, 2019; Revised August 06, 2019;

Accepted September 03, 2019
서는 2100년 우리나라의 평균 폭염일수를 약 28.5 일로 예측하였는데(KMA, 2018), 2018년에 이미 이에 근접한 정도의 폭염이 발생하고 있는 실정이다. 다른 보고에서 도 마찬가지로 2017 2100년 폭염일이 한달 이상 발생하 는 지역은 우리나라 전체면적의 $85.3 \%$ 로, 전주지역에서 약 50.8일이 발생하는 것으로 나타났다 (Park 등, 2013). 따라서 기후변화 시나리오 중 최악의 경우(RCP 8.5), 우 리나라의 농작물 경작가능지역은 모두 폭염의 영향에서 벗어나기 어려우며 이에 따른 농작물의 피해 역시 매년 증가할 것으로 보인다.

포도의 경우 시기별 고온의 영향을 살펴보면, 7월에는 고온에 의한 증산량 증가로 과립비대가 불량한 피해를 받게 되고, 착색기인 8 월에 고온이 발생하면 성숙기가 지연되며 특히 야간고온으로 인해 붉은색에서 검은색으 로의 착색이 어려워 지고 착색이 중단된다(Downey 등, 2006, Mori 등., 2007, Tarara 등, 2008). 이와 같은 직접 적인 과실특성에 대한 피해 이외에도 우리나라에서 다발 하는 고온피해로는 엽소와 축과 증상이 대표적으로 나타 나는데, 포도의 엽소와 축과 증상은 일시적으로 증산량 이 증가할 때 잎, 과실에서 수분을 빼앗겨 발생하는 증 
상이다(RDA, 2018). 여름철 고온으로 인하여 갑자기 늘 어난 증산량 보충을 위해 농가에서는 포도과원의 일일 관수량을 늘리게 된다. 이때 토양배수가 불량한 포도과 원의 경우, 뿌리의 호흡불량으로 관수량을 늘렸음에도 불구하고 지상부에 충분한 수분공급이 어려워 엽소와 축 과 같은 현상이 발생하며, 배수불량 과원에서는 매년 빈 발하는 생리장해이다. 이러한 증상의 원인은 과도한 온 도 상승으로 인한 증산량의 증가인데 시설재배가 아닌 노지의 비가림재배 포도과원에서도 여름철 온도 상승과 답 전환과원의 증가로 이러한 증상이 늘어나고 있다. 따 라서 노지 비가림 시설에서 비가림 내의 온도상승을 억 제하고 이를 제어할 수 있는 기술이 개발된다면 고온으 로 인한 축과, 엽소와 같은 온도관련 생리장해는 물론 과실품질 악화를 방지할 수 있게 되므로 매우 중요하다.

백색수성페인트와 같은 차광도포제를 처리하는 방법은 온실의 열기를 감소시키기 위해 세계적으로 널리 사용되 는 온도관리 방법 중 하나이다(Baille 등, 2001). 수성페 인트의 경우 그 효과가 유리, 비닐을 통해 투과되는 광 량에 영향을 주고(Cohen 등, 2005), 특히 NIR 영역뿐만 아니라 식물에 유효한 $400 \mathrm{~nm} \sim 700 \mathrm{~nm}$ 의 영역도 같이 투과량이 감소하므로(Elsner, 2005) 작물의 생육, 형태에 영향을 준다 $(\mathrm{Li}$ 등, 2010). 우리나라에서도 최근 시설하 우스의 고온장해를 경감하기 위해 차광도포제를 이용하 는 방법이 개발되었고, 딸기, 파프리카 등 과채류 시설 하우스 재배작물에서 주로 시험되었다(Lee 등, 2016). 차광도포제 처리는 밀폐된 온실환경이나 시설하우스에서 는 온도감소 효과 및 실용성이 입증되었지만, 포도 재배 면적의 $70 \%$ 이상을 차지하고 있는 비가림 시설에 대한 효과는 아직 검증된바 없다. 포도 비가림 시설은 강우를 방지하여 병을 물리적으로 방제하기 위한 효과적인 시설 이지만, 여름철 비가림 내부의 온도 상승은 피할 수 없 다(Kim 등, 2015). 따라서 본 시험을 통해 포도 비가림 시설에 차광도포제 처리시 온도감소 효과를 조사하여 포 도 비가림 시설과 같은 밀폐되지 않은 시설에서의 적용 가능성을 검토하였다.

\section{재료 및 방법}

\section{1. 차광도포제 처리 및 온도조사}

완주에 위치한 국립원예특작과학원 포도 재배 시험포 장를 활용하여 차광도포제 시험을 수행하였다. 시험포장 은 개량 비가림 시설이 갖춰진 $2.7 \mathrm{~m} \times 2.7 \mathrm{~m}$ 간격으로 재식 된 4년생 '캠벨얼리' 포장으로 차광도포제 시험을 위해 각 $1,640 \mathrm{~m}^{2}$ 면적의 2 곳의 시험포장을 이용하였다. 마찬가지로 '거봉' 품종은 $3 \mathrm{~m} \times 3 \mathrm{~m}$ 간격으로 재식 된 $1,640 \mathrm{~m}^{2}$ 면적의 '거봉' 포장 1 곳을 이용하였다. 차광도
포제 농도 별 시험처리를 위해 시중에서 구입한 차광도 포제 (Whiteshade, Ecofarm, Jeonju, Korea)를 이용하여 각 포도 재배시험포장 $\left(1,640 \mathrm{~m}^{2}\right)$ 을 4 등분하여 차광도포 제의 농도를 $0,15,25,35 \%$ 로 조절하여 각각 분무 처 리하였다. 차광도포제의 차광효과를 비교하기 위해 광합 성 광량자속 밀도(PPFD, Photosynthesis Photon Flux Density) 를 측정하여 비교하였다(Spectrum technologies, quantum light sensor \#366816, USA). PPFD는 광합성 에 유효한 파장인 $400 \sim 700 \mathrm{~nm}$ 의 영역대의 에너지의 시 간 별 누적 값으로 식물생장에 필요한 광의 양을 비교 하는데 사용되는 지표이다(McCree, 1966, 1972). 차광도 포제 처리기간 중 8 월 3 일 $\sim 8$ 월 10 일 사이의 맑은 날 오후 2시를 기준으로 비가림 밖의 PPFD를 측정하고, 동 시에 각 차광 처리 별 비가림 아치 밑부분의 신초 유인 덕시설에서 $\mathrm{PPFD}$ 를 처리 별 10 반복 측정하여 비교하 였다. 포도의 신초 위쪽 비가림 상부와 포도과실이 위치 한 하부의 온도 차이를 비교하기 위해 온습도계 (Lascar, EL-USB 2, UK)를 비가림 아치 밑부분 신초유 인 덕시설에 1 곳 과방이 위치한 부분에 1 곳, 총 2 부 분에 설치하였으며, 차광도포제 처리구별로 2 지점에 설 치하여 온도를 측정하였다. 온도는 처리기간 (8월 3일 9월 30일)의 온도 변화를 1 시간 단위로 기록하였다. 데 이터를 획득한 뒤 차광도포제 처리간 온도 비교는 일일 중 가장온도가 높은 12 시 17 시까지의 평균온도를 비교하였다.

\section{2. 과실품질 조사}

차광도포제의 희석 농도 별 차광 처리구 과실의 품질 특성을 비교하기 위해 가용성 고형물 함량, 적정산도는 다음과 같은 방법으로 수행하였다. 차광도포제 처리구별 무작위로 3 주의 포도나무로부터 주당 20 개의 송이를 수확한 뒤 그 중 5 개의 송이를 선택하여 과립을 각각 5 립씩 채취하고 거즈로 감싼 뒤 압착한 과즙으로 가용 성 고형물 함량 (Total soluble solids, TSS) 및 적정산도 (Titratable acidity, TA)를 측정하였다. 가용성 고형물 함 량은 휴대용 굴절 당도 측정기(PAL-1, ATAGO, Japan) 를 이용하여 측정하였으며, 적정산도는 자동적정산도기 (Titroline easy, Schott, Germany)를 사용하여 과즙 $5 \mathrm{ml}$ 에 증류수 $20 \mathrm{ml}$ 을 넣은 다음 $0.1 \mathrm{~N} \mathrm{NaOH}$ 를 이용하여 $\mathrm{pH}$ 8.2로 적정한 $0.1 \mathrm{~N} \mathrm{NaOH}$ 양에 해당하는 산도를 포도의 주요 유기산인 tartaric acid의 함량으로 환산하여 나타내었다(Jung 등 2010). 가용성 고형물 함량 및 적정 산도는 처리구별 각각 5 회 반복하여 시료를 채취하여 측정하였다. 과립중은 차광도포제 처리구별 무작위로 3 주의 포도나무로부터 주당 20 개의 송이를 수확한 뒤 그 중 5 개의 송이를 선택하여 과립을 각각 5 립씩 채 
취하고 총 25 개의 과립의 무게를 소수점 2 자리까지 기 록하였다. 종경, 횡경은 동일한 과립을 디지털 캘리퍼스 를 이용하여 측정하였다. 과피색은 과실특성조사에서 사 용한 송이에서 무작위로 10 개의 과립을 색차계 (CR300 , Minolta, Japan)를 이용하여 Hunter L*, c*, h*값을 얻고 CIRG값(Color Index for Red Grape)은 다음식을 이용하여 계산하였다.

$$
\text { CIRG }=(180-h) /\left(L^{*}+c^{*}\right)
$$

단 위의 식에서 $\mathrm{h}$ 값이 $270^{\circ}$ 와 $360^{\circ}$ 사이일 경우에는 $360^{\circ}$ 과의 차이에 마이너스 값으로 대체하여 계산하였다 (Carreno 등, 1995).

\section{3. 통계분석}

차광도포제의 농도처리별 조사한 광량, 온도, 과실특성 데이터는 통계프로그램인 'R'(Ver. 3.5.0.)의 'Rcmdr' package(Ver. 2.5.3.)를 이용하여 Tukey's multiple range test를 수행하였으며, 동일 농도 차광도포제 처리에서의 비가림 시설 내 높이에 따른 온도 차이는 T-test를 실시 하여 유의성을 검정하였다.

\section{결과 및 고찰}

1. 차광도포제 처리에 따른 광량 및 온도의 변화

2018년 폭염피해가 절정에 다다른 기간(8월 3일 10
일) 중 노지의 $\mathrm{PPFD}$ 값은 $2,100 ~ 2,300 \mu \mathrm{mol} \cdot \mathrm{m}^{-2} \cdot \mathrm{s}^{-1}$ 범위 를 나타냈으며, 차광도포제 $15 \%$ 처리시 $1,539 \mu \mathrm{mol} \cdot \mathrm{m}^{-2} \cdot \mathrm{s}^{-1}$ 로 약 $32 \%, 25 \%$ 처리시 $1.223 \mu \mathrm{mol} \cdot \mathrm{m}^{-2} \cdot \mathrm{s}^{-1}$ 로 $45 \%$, $35 \%$ 처리시 $1,184 \mu \mathrm{mol} \cdot \mathrm{m}^{-2} \cdot \mathrm{s}^{-1}$ 로 무처리 대비 $48 \%$ 감 소하였다(Table 1). 무처리와 비교하였을 때 차광도포제 처리구의 경우 육안으로도 처리농도 별 구분이 가능하였 고, 실제 포도 비가림 시험포장 지면의 밝기에도 차이를 보였다(Fig. 1). 포도는 광포화점이 $700 ~ 900 \mu \mathrm{mol} \cdot \mathrm{m}^{-2} \cdot \mathrm{s}^{-1}$ 가량으로 낮은 과수이며(Cartechini 와 Palliotti, 1995), 한여름의 경우 비가림 처리구의 포도잎이 오히려 광합성 효율이 높은 데 이는 비가림에 사용한 비닐이 과도한 햇빛을 차단한 효과로 과도한 광에 의해 발생하는 광 저해반응을 방지하기 때문인 것으로 알려져 있다 (Chavarria 등, 2012). 본 시험의 결과에서 가장 농도가

Table 1. Photosynthesis photon flux density of plastic film rain shelter in different shading paint concentration. (2018. 8. 5. 14:00).

\begin{tabular}{ccc}
\hline \hline \multicolumn{2}{c}{ Concentration (\%) } & PPFD $^{\mathrm{z}}$ \\
\hline \multirow{2}{*}{ Shading } & 15 & $1,539 \mathrm{c}^{\mathrm{y}}$ \\
Paint & 25 & $1,223 \mathrm{~d}$ \\
& 35 & $1,184 \mathrm{~d}$ \\
\multicolumn{2}{c}{ Control (Plastic film only) } & $1,704 \mathrm{~b}$ \\
\hline \multicolumn{2}{c}{ Field } & $2,288 \mathrm{a}$ \\
\hline
\end{tabular}

${ }^{\mathrm{z}}$ PPFD (Photosynthesis photon flux density), $\mu \mathrm{mol} \cdot \mathrm{m}^{-2} \cdot \mathrm{sec}^{-1}$

${ }^{\mathrm{y}}$ Means with the same letter are not significantly different at $5 \%$ by Tukey's HSD
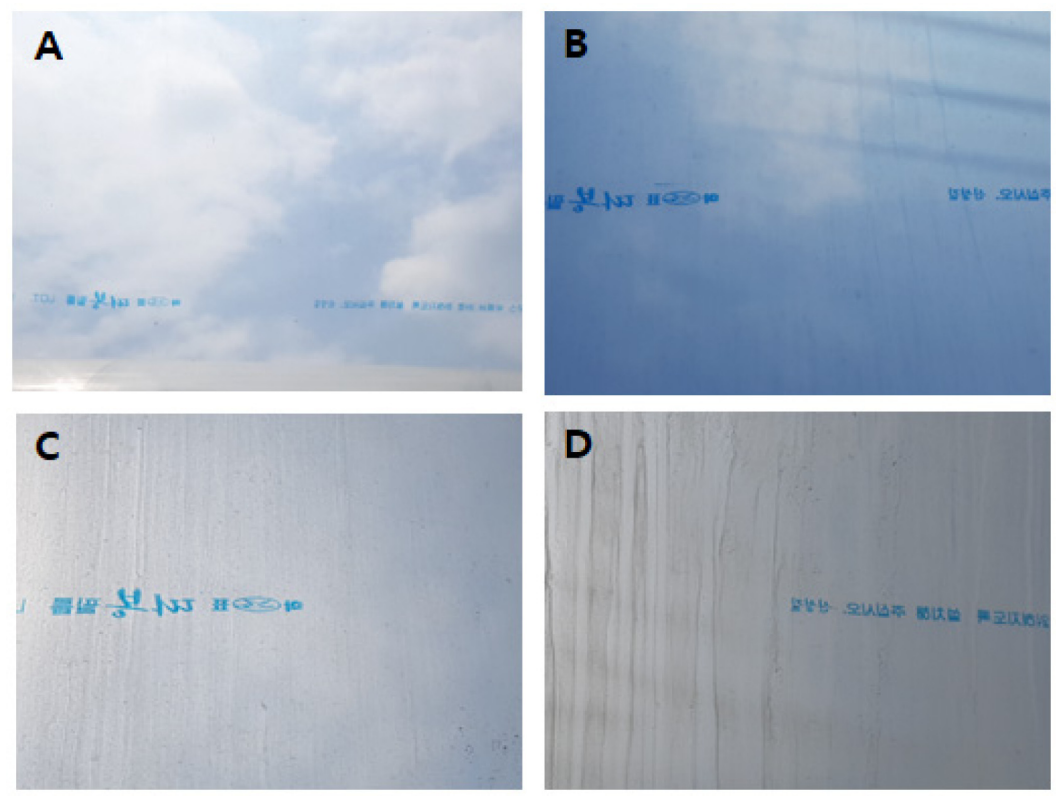

Fig. 1. Transparency differences in plastic film rain shelter in different shading paint concentration. A, No treatment, B, $15 \%$ application, C, $25 \%$ application, D, $35 \%$ application. 
높은 차광도포제 $35 \%$ 처리 구에서의 $\mathrm{PPFD}$ 는 약 $1,184 \mu \mathrm{mol} \cdot \mathrm{m}^{-2} \cdot \mathrm{s}^{-1}$ 정도로 나타나 포도가 요구하는 광포화 점을 넘는 충분한 광량으로 조사되었다. 하지만 이는 한 여름의 맑은날 측정 기준으로서 날씨가 흐린 경우, 본 시험의 $35 \%$ 차광도포제 처리는 약 $48 \%$ 이상의 차광효 과를 가지므로 아무리 광포화점이 낮은 과수인 포도라 할지라도 광합성에 영향을 줄 수 있다. 차광도포제는 $\mathrm{UV}, \mathrm{PAR}, \mathrm{IR}$ 등 전 영역에서 차단효과가 있는 것으로 알 려져 있으며, 본 시험의 $35 \%$ 차광도포제 처리는 앞서서 보고된 딸기육묘하우스에서 시험된 결과와 유사한 광량 감소효과를 보였다(Lee 등, 2016). 본 시험에서 비가림 비 닐 외부에 분무처리하는 차광도포제의 특성상 완전히 고 르게 칠이 되지는 않지만 일반적으로 농약방제에 사용하 는 약대를 이용한 분무도포에도 비교적 균일한 농도를 유 지 하였으며 차광 정도도 농도 처리 별 차이가 육안으로 도 차이가 날 정도로 뚜렷하게 구분되었다(Fig. 1).

포도에 사용하는 비가림 시설은 설치규격에 따라 다르 지만 일반적으로 노지와 비교할 때, 피복비닐로 인해 약 $3^{\circ} \mathrm{C}$ 의 온도상승이 일어나며, 비가림 아치와 신초 유인 덕면이 일정 간격 떨어져 있으면 온도의 차이가 감소한 다(Lee 등, 1999; Kim 등, 2015). 또한 비가림 폭이 늘 어나면 늘어날수록 노지와 비교할 때 비가림 내부 온도 상승폭이 증가한다(Kim 등, 2015). 일반 시설하우스와 동일하게 포도의 비가림 시설도 비가림 아치의 동고와 비가림 아치의 간격, 비가림 아치와 덕면과의 거리, 그 리고 비가림 내부의 수형에 따라서 비가림 내부의 온도 는 크게 영향 받는다. 본 시험결과 중 수관상부의 덕면 온도는 차광도포제 처리 농도 별로 대조구와 큰 차이가 없었는데 그 이유는 비가림 아치의 크기가 길이 $2.4 \mathrm{~m}$, 높이 $90 \mathrm{~cm}$ 의 반원으로 공간이 매우 협소하고 비가림 아 치 내부로 환기가 되지 않아 차광을 하더라도 지면의 복사열, 포도잎의 반사열이 비가림 아치 내에 축적된다. 따라서 비가림 아치와 가까운 비가림 덕면은 비가림 아 치 내부의 온도와 비슷한 온도를 나타내고 차광도포제 처리농도와 관계없이 모두 일정한 온도를 나타낸 것으로 판단된다. 폭염피해 기간(8월 3 일 10일) 중 본 시험에 서 12시 17시까지의 외부기온 평균은 $35.4^{\circ} \mathrm{C}$ 였고 비가 림 상부의 온도는 이보다 $5^{\circ} \mathrm{C}$ 가량 높은 $41 \sim 42^{\circ} \mathrm{C}$ 로 나 타났다. 포도 'Semillion' 품종에서 조사한 결과에서 $40^{\circ} \mathrm{C}$ 에서 4 일간 처리한 나무의 기공전도도는 상온 대 비 $95 \%$ 가량 감소한 것으로 보고하고 있다(Greer 등, 2010). 위의 사례가 아니더라도 일반적으로 식물의 엽온 이 증가하면 광합성으로 얻는 에너지보다 더 많은 에너 지를 호흡으로 소모하게 된다. 노지에서 재배하는 포도 의 경우 그늘에 있는 과방과 햇빛에 노출된 과방의 경 우 약 $2.4^{\circ} \mathrm{C}$ 의 차이를 나타내며(Smart 와 Sinclair,
Table 2. Temperatures of plastic film rain shelter in different shading paint concentration.

\begin{tabular}{cccc}
\hline \hline $\begin{array}{c}\text { Concentration } \\
\text { of shading paint } \\
(\%)\end{array}$ & \multicolumn{2}{c}{ Temperature $\left({ }^{\circ} \mathrm{C}\right)$} & t-test \\
\cline { 2 - 3 } & $\begin{array}{c}\text { Under rain } \\
\text { shelter }\end{array}$ & Bunch & \\
\hline 15 & $41.2 \mathrm{a}$ & $37.3 \mathrm{ab}$ & $* *$ \\
25 & $41.4 \mathrm{a}$ & $37.8 \mathrm{ab}$ & $* *$ \\
35 & $41.8 \mathrm{a}$ & $36.4 \mathrm{~b}$ & $* *$ \\
Control & $42.4 \mathrm{a}$ & $38.6 \mathrm{a}$ & $* *$ \\
\hline
\end{tabular}

${ }^{\mathrm{z}}$ Average temperature (2018. 8.3. 8.10. 12:00 17:00). Ambient temperature is $35.4^{\circ} \mathrm{C}$

** Correlation is significant at the 0.01 level (2-tailed)

1976), 엽온의 경우 그늘에 있는 잎보다 햇빛에 노출된 잎의 엽온이 $5 \sim 10^{\circ} \mathrm{C}$ 높은 것으로 알려져 있다(Kliewer 와 Lider, 1968). 위의 결과로 볼 때 외기 온도가 $35^{\circ} \mathrm{C}$ 를 상회하는 경우 차광여부에 따라 엽온의 증가에 영향 을 미치며 이는 기공전도도 감소와 과실품질에도 영향을 미친다는 점을 유추할 수 있다.

폭염피해 기간 중(8월 3 일 10일) 차광도포제 $35 \%$ 처리 시 수관상부 덕면의 온도는 무처리와 큰 차이를 보이지 않은 반면 수관하부 과방 부위의 온도는 약 $2^{\circ} \mathrm{C}$ 낮은 것으로 나타났다(Table 2). 우리나라의 비가림 시설 은 개량일자형 수형과 결합된 독특한 재배형태로 인해 하우스에서의 온도분포와는 조금 다른 양상을 나타낸다. 우리나라 포도 비가림 하부의 온도는 포도의 신초가 $\mathrm{Y}$ 자 형태로 사립 유인되는 특성으로 어느 방향으로 햇살 이 비치던 지면에는 그늘이 형성되고 신초와 포도잎으로 구성된 일종의 울타리가 형성되어 윗부분의 뜨거운 열기 가 아래쪽으로 쉽게 전파되지 않는 특성을 나타낸다. 따 라서 수관상부 덕면의 온도는 아무리 차광처리를 한다고 해도 상하부간 공기의 유동이 부족하여 비닐피복으로 인 한 열기가 지속적으로 축적될 수밖에 없다. 반면 비가림 하부 $(140 \mathrm{~cm})$ 는 외부에 사방으로 노출되어 있어 비교적 쉽게 외부와 온도교환이 이루어진다. 따라서 차광도포제 를 처리한 경우 수관하부 과방 부위에서는 비가림 내부 로 인입하는 일사량이 감소하는 효과로 무처리구 또는 같은 처리구의 수관상부 덕면에 비하여 낮은 온도를 나 타내었다(Table 2).

\section{2. 차광도포제 처리에 따른 과실품질의 변화}

차광도포제를 비가림 비닐 외부에 처리하면 적외선 투 과량 감소로 인한 온도저하 외에도 유효파장의 광량감소 로 인한 작물의 광합성 량 감소가 우려된다. 일반적으로 포도에서 시험된 차광 관련 논문을 살펴보면 생육시기별 차광에 의한 광합성효율저하 및 건물중 감소는 개화기에 
정성민 · 허윤영 · 임동준 · 정경호

Table 3. Fruit characters of 'Campbell Early' grape in different shading paint concentration treatment on plastic film rain shelter.

\begin{tabular}{cccccccc}
\hline \hline $\begin{array}{c}\text { Shading paint } \\
\text { concentration } \\
(\%)\end{array}$ & $\begin{array}{c}\text { Total Soluble } \\
\text { Solids } \\
\left({ }^{\circ} \mathrm{Bx}\right)\end{array}$ & $\begin{array}{c}\text { Titratable } \\
\text { Acidity } \\
(\%)\end{array}$ & $\begin{array}{c}\text { Berry Weight } \\
(\mathrm{g})\end{array}$ & $\begin{array}{c}\text { Berry Width } \\
(\mathrm{mm})\end{array}$ & $\begin{array}{c}\text { Berry Length } \\
(\mathrm{mm})\end{array}$ & $\begin{array}{c}\text { Berry } \\
\text { Hardness } \\
(\mathrm{kg} \cdot \mathrm{f})\end{array}$ & $\begin{array}{c}\mathrm{CIRG}^{\mathrm{y}} \\
15\end{array}$ \\
\hline $17.0 \mathrm{bc}^{\mathrm{z}}$ & $0.49 \mathrm{a}$ & $5.9 \mathrm{ab}$ & $20.9 \mathrm{~b}$ & $20.1 \mathrm{a}$ & $1.72 \mathrm{ab}$ & $5.7 \mathrm{a}$ \\
25 & $16.3 \mathrm{c}$ & $0.48 \mathrm{a}$ & $5.5 \mathrm{~b}$ & $20.5 \mathrm{~b}$ & $19.2 \mathrm{~b}$ & $1.60 \mathrm{bc}$ & $6.0 \mathrm{a}$ \\
35 & $18.1 \mathrm{a}$ & $0.45 \mathrm{a}$ & $6.5 \mathrm{a}$ & $21.9 \mathrm{a}$ & $20.6 \mathrm{a}$ & $1.88 \mathrm{a}$ & $5.8 \mathrm{a}$ \\
Control & $17.3 \mathrm{ab}$ & $0.49 \mathrm{a}$ & $5.4 \mathrm{~b}$ & $20.3 \mathrm{~b}$ & $19.1 \mathrm{~b}$ & $1.38 \mathrm{c}$ & $5.8 \mathrm{a}$ \\
\hline
\end{tabular}

${ }_{\mathrm{Z}}$ Means with the same letter are not significantly different at the $5 \%$ by Tukey's HSD

${ }^{y}$ Color Index for Red Grape

Table 4. Fruit characters of 'Kyoho' grape in different shading paint concentration treatment on plastic film rain shelter.

\begin{tabular}{cccccccc}
\hline \hline $\begin{array}{c}\text { Shading paint } \\
\text { concentration } \\
(\%)\end{array}$ & $\begin{array}{c}\text { Total Soluble } \\
\text { Solids } \\
\left({ }^{\circ} \mathrm{Bx}\right)\end{array}$ & $\begin{array}{c}\text { Titratable } \\
\text { Acidity } \\
(\%)\end{array}$ & $\begin{array}{c}\text { Berry Weight } \\
(\mathrm{g})\end{array}$ & $\begin{array}{c}\text { Berry Width } \\
(\mathrm{mm})\end{array}$ & $\begin{array}{c}\text { Berry Length } \\
(\mathrm{mm})\end{array}$ & $\begin{array}{c}\text { Berry } \\
\text { Hardness } \\
(\mathrm{kg} \cdot \mathrm{f})\end{array}$ & $\begin{array}{c}\text { CIRG }^{\mathrm{y}} \\
\text { ( })\end{array}$ \\
\hline 15 & $20.3 \mathrm{a}^{\mathrm{z}}$ & $0.57 \mathrm{a}$ & $7.28 \mathrm{~b}$ & $23.4 \mathrm{~b}$ & $21.0 \mathrm{~b}$ & $3.07 \mathrm{a}$ & $4.9 \mathrm{a}$ \\
25 & $19.2 \mathrm{~b}$ & $0.50 \mathrm{~b}$ & $7.67 \mathrm{ab}$ & $23.7 \mathrm{ab}$ & $22.5 \mathrm{a}$ & $3.02 \mathrm{a}$ & $4.9 \mathrm{a}$ \\
35 & $20.6 \mathrm{a}$ & $0.49 \mathrm{~b}$ & $8.56 \mathrm{a}$ & $25.1 \mathrm{a}$ & $22.8 \mathrm{a}$ & $2.83 \mathrm{ab}$ & $5.0 \mathrm{a}$ \\
Control & $20.3 \mathrm{a}$ & $0.49 \mathrm{~b}$ & $7.50 \mathrm{~b}$ & $24.2 \mathrm{ab}$ & $22.0 \mathrm{ab}$ & $2.59 \mathrm{~b}$ & $4.9 \mathrm{a}$ \\
\hline
\end{tabular}

${ }_{\mathrm{Z}}$ Means with the same letter are not significantly different at the $5 \%$ by Tukey's HSD.

${ }^{y}$ Color Index for Red Grape

가장 크게 나타나며 $(\mathrm{Gu}$ 등, 1996, Prieto 등, 2010), $50 \%$ 차광시 탄소동화율이 $20 \%$ 감소하는 것으로 알려져 있다(Heuvel 등, 2004). 본 시험의 차광도포제 처리시기 는 변색기(거봉) 성숙기(캠벨얼리)로서 차광도포제 농 도 별 과실품질을 비교한 결과 폭염피해 기간 중 $(8$ 월 3 일 10일) 차광도포제 $35 \%$ 처리에서만 무처리구와 유 의한 차이를 나타내었다. '캠벨얼리' 품종에서는 당도, 과립중, 종경, 횡경, 경도 등에서 무처리구에 비해 유의 한 차이를 나타내었다(Table 3). 이는 조생종인 '캠벨얼 리' 품종의 특성으로 인해 본격적인 고온피해 이전에 과 실의 생장이 일부 진행된 결과로 보인다. 포도 과립에는 Sugar transporter와 sucrose metabolic enzyme이 존재하 며 성숙기에 과립으로 자당을 능동 수송하게 되는데 고 온조건은 이들 효소 유전자의 발현이 억제된다(Pillet 등, 2012)라는 보고로 볼 때 과방부위의 온도 차이로 인한 당도의 저하는 충분히 예상 가능한 결과였다. 만생종인 '거봉' 품종에서는 단지 과립중이 무처리구에 비해 유의 한 차이를 나타내었다(Table 4). '거봉'품종의 경우 변색 기에 처리된 차광도포제의 효과가 나타날 것으로 기대하 였으나, 고온에 따른 과실품질의 차이는 품종간 차이를 보인다는 보고(Downey 등, 2006), 또한 '거봉'품종의 품 질에 악영향을 미치는 극단적인 고온으로 인해 차광도포 제 처리효과가 나타나지 않은 것으로 보인다. 위의 결과 를 뒷받침하는 조사결과로 고온 시 산도의 급격한 감소 를 볼 수 있는데, 8월 3일 차광도포제를 처리한 뒤 8월
말 수확한 '캠벨얼리'와 '거봉'의 과실품질에서 모두 동 일하게 모든 처리구의 산도가 매우 낮았다. 폭염피해가 본격화 되고 착색이 시작되기 이전인 7월 중순부터 처 리가 되었다면 각 품종 모두 차광도포제 처리 별 과실 품질은 크게 차이가 나타났을 것으로 판단된다.

'캠벨얼리'포도에서는 처리구에 상관없는 착색 정도를 나타내었다 (Table 3), 조생종인 '캠벨얼리' 품종의 특성 상 착색에 영향 받는 변색기(7월 20일, 전주기준) 이후 에 본격적인 고온피해를 받아 차광도포제 처리에 의한 착색에 차이가 없었다. 반대로 변색기에 고온을 맞이한 '거봉' 품종에서는 모든 처리구에서 과방의 착색이 양호 하지 못하고 붉은색을 나타냈다(CIRG 값 5 이하, Table 4). 아무리 차광도포제 처리를 한다 하더라도 온도 측정 결과에서 보듯 비가림 내부 과방부위의 온도가 외기온도 이하로 유지되지는 않기 때문에, $35^{\circ} \mathrm{C}$ 이상의 주간고온 은 착색에도 불리할 뿐 아니라 과방자체의 과도한 호흡 으로 인한 당도와 산도의 저하를 유도한다. 'Merlot' 품 종을 대상으로 수행된 시험에서 과방의 온도에 따른 품 질은 극명한 차이를 나타내었는데 그늘에서의 고온은 정 상인 상태보다 급격한 안토시아닌 농도 저하와 적정산도 의 감소를 유도한다(Spayd 등, 2002). 포도 과방에 고온 을 처리하면 일반적으로 안토시아닌 생합성에 관계된 유 전자의 발현량이 감소하면서 안토시아닌 함량이 감소한 다(Downey 등, 2006, Mori 등, 2007). 특히 이러한 변 화는 야간온도에 많이 좌우되는 것으로 알려져 있다 
(Koshita 등, 2007). 따라서 '거봉'에서 나타난 착색불량 결과는 여름철 주야간 고온과 관련한 많은 보고를 통해 충분히 개연성이 있는 결과로 보인다. 변색기 이후의 차 광도포제 처리는 수확기 과실품질에 유의한 차이를 나타 내기에는 처리시기가 짧았다. 특히 차광도포제를 처리했 다 하더라도 포도 비가림 시설의 특성상 주위의 기온보 다 낮아지는 것은 아니므로 고온에 의한 착색불량, 산도 감소까지 막을 수는 없었으며 다만 급격한 온도 상승으 로 인한 광합성 저해와 과다한 호흡으로 인한 광합성 산물의 축적불량에는 효과가 있을 것으로 판단된다. 따 라서 폭염피해가 예측되는 경우 응급조치로 차광도포제 를 긴급 도포하여 피해를 최소화 하는 정도의 효과는 인정되며, 변색기를 앞두고 차광도포제를 처리한다면 과 실품질에도 차이를 보일 것으로 기대된다.

한편 하우스에 처리한 차광도포제의 경우 $35 \%$ 도포 후 약 2 개월이 경과하면 차광률이 $34 \%$ 에서 $18 \%$ 로 감 소한다는 보고(Lee 등, 2016)와 유사하게 본 시험에서도 약 3 개월 경과 후 $35 \%$ 처리에서만 빗물이 닿지 않는 부위에만 흔적을 찾을 수 있었다. 만약 극단적인 처리로 서 $50 \%$ 까지 차광도포제를 처리한다면 광보상점이 낮은 포도나무의 특성상 여름철에는 당해년도 차광에 따른 광 량부족은 일어나지 않았겠지만, 그만큼 자연적인 제거가 어려워 별도의 제거제를 이용한 제거가 필요할 것으로 보인다. 그렇지 않을 경우 제거되지 못한 차광도포제가 남고, 포도나무의 생육초기부터 차광할 때 주간부를 제 외한 엽, 신초, 뿌리의 건물중이 $10 \sim 20 \%$ 감소하고 (Heuvel 등, 2004), 빈가지 발생율이 현저히 증가한다는 보고(Perez 와 Klewer, 1990)로 볼 때 차년도 생장에 영 향을 미칠 것으로 판단된다.

지금까지 포도 비가림 시설에 대한 차광도포제의 처리 효과를 확인한 결과 차광에 따른 광량의 감소 및 그에 따른 온도감소 효과를 확인할 수 있었다. 다만 비가림 시설의 특성상 차광도포제 처리구의 기온이 외부 기온보 다 낮게 유지되지는 않았기 때문에 본 시험과 같이 변 색기 이후의 차광도포제 처리에 의한 과실품질 향상효과 는 크게 나타나지 않았다. 포도 과립의 색과 맛이 결정 되는 변색기 이전부터 차광도포제 처리를 한다면 비가림 내부의 온도상승 방지와 함께 과실품질의 향상도 기대할 수 있을 것이다.

\section{적 요}

차광도포제 처리는 시설하우스 내부의 고온 제어를 위 한 유용한 관리 방법 중 하나로 이용되고 있다. 우리나 라 포도과원에 설치된 비가림 시설은 강우를 방지하여 병 발생을 예방하는 독특한 시설로 여름철 고온 피해를
받을 가능성이 높다. 본 시험에서는 포도 비가림 시설 아래의 과도한 고온을 회피하기 위해 차광도포제의 농도 를 달리하여 비가림 비닐 외부에 처리하였다. 그 결과 $35 \%$ 차광도포제 처리는 비가림 비닐 아래의 PPFD (광 합성 광양자 자속 밀도)의 $45 \%$ 를 감소시켰다. 또한 $35 \%$ 차광도포제 처리는 무처리 대비 과방부위 온도를 $2^{\circ} \mathrm{C}$ 를 낮추는 결과를 나타냈다. 차광도포제 처리는 포도 비가림 시설에서 유의하게 온도를 낮추는 효과가 확인되 었지만 주변 온도보다 낮은 온도로 제어 할 수는 없었 다. 자연적으로 제거되는 $35 \%$ 차광도포제 처리는 우리 나라의 포도 비가림 시설내의 여름철 과도한 열 손상과 과일 품질 저하를 방지하는 방법으로 활용할 수 있다.

추가 주제어: 폭염, 백색수성페인트

\section{사 사}

이 논문은 2018년도 원예특작시험연구비로 수행된 연 구임 (PJ014094012018).

\section{Literature Cited}

Baille, A., C. Kittasand, and N. Katsoulas. 2001. Influence of whitening on greenhouse microclimate and crop energy partitioning. Agric. For. Meteorol. 107: 293-306.

Carreno, J., A. Martinez, L. Almela, and J.A. FernandezLopez. 1995. Proposal of an index for the objective evaluation of the color of red table grapes. Food Res. Int. 28:373377.

Cartechini A. and A. Palliotti. 1995. Effect of shading on vine morphology and productivity and leaf gas exchange characteristics in grapevines in the field. Am. J. Enol. Vitic. 46: 227-234.

Chavarria, G., H.P. Dos Santos, L.A.S. De Castro, G.A.B. Marodin, and H. Bergamaschi. 2012. Anatomy, chlorophyll content and photosynthetic potential in grapevine leaves under plastic cover. Rev. Bras, Fruitic. Jaboticabal. 34:661668.

Cohen, S., E. Raveh, Y. Li, A. Grava, and E.E. Goldschmidt. 2005. Physiological responses of leaves, tree growth and fruit yield of grapefruit trees under reflective shade screens. Sci. Hortic. 107: 25-35.

Downey, M.O., N.K. Dokoozlian, and M.P. Kristic. 2006. Cultural practice and environmental impacts on the flavonoid composition of grapes and wine. Am. J. Enol. Vitic. 57:257268.

Elsner, B.V. 2005. Interference pigments in photo selective shading paint for greenhouses. Acta Hortic. 711:417-422.

Greer, D.H. and C. Weston. 2010. Heat stress affects flower- 
ing, berry growth, sugar accumulation and photosynthesis of Vitis vinifera $\mathrm{cv}$. Semillon grapevines grown in a controlled environment. Funct. Plant Biol. 37: 206-214.

Gu, S., P.B. Lombard, and S.F. Price. 1996. Effect of shading and nitrogen source on growth, tissue ammonium and nitrate status, and inflorescence necrosis in Pinot Noir grapevines. Am. J. Enol. Vitic 47:173-180.

Heuvel, J.E.V., J.T.A Proctor, K.H. Fisher and J.A. Sullivan. 2004. Shading affects morphology dry matter partitioning and photosynthetic response of greenhouse grown Chardonnay grapevines - Hortscience 39:65-70.

IPCC, 2014: Climate change 2014: Synthesis report. Contribution of working groups I, II and III to the fifth assessment report of the intergovernmental panel on climate change [Core writing team, R.K. Pachauri and L.A. Meyer (eds.)]. IPCC, Geneva, Switzerland, 151 pp.

Jung, S.M., E.H. Chang, S.J. Park, S.T. Jeong, J.H. Roh, Y.Y. Hur, and H.C. Lee. 2010. Berry thinning effects on the fruit and wine quality of grape 'Muscat Bailey A'. Korean J. Food Preserv. 17: 625-630. (in Korean)

Kim, S.J., S.J. Park, Y.Y. Hur, J.C. Nam, S.W. Ko, and S.M. Jung. 2015. Fruit quality and occurrence of brown leaf spot disease (Pseudocercospora vitis) according to the width of plastic shelter in the grape 'Campbell Early'. Protected Hort. Plant Fac. 24:113-118. (in Korean)

Kliewer, W.M., and L.A. Lider. 1968. Influence of cluster exposure to the sun on the composition of Thompson Seedless fruit. Am. J. Enol. Vitic. 19:175-284.

KMA (Korea Meteorological Administration). 2018. The prospect report of climate change in Korean peninsula. (In Korean)

Koshita, Y., T. Asakura, H. Fukuda, and Y. Tsuchida. 2007. Nighttime temperature treatment of fruit clusters of 'Aki Queen' grapes during maturation and its effect on the skin color and abscisic acid content. Vitis 46:208-209.

Lee, J.C., J.H. Kim, C.J. Yun, and M.D. Cho. 1999. Studies on standardization in cultivation under shelter for improvement of grape fruit quality. Research report. Chungnam Univ. Ministry of Agriculture and Forest. (in Korean)

Lee, J.H., J.K. Kwon, Y.J. Ham, M.R. Yun, K.S. Park, H.G. Choi, K.H. Yeo, J.S. Lee, and B. Khoshimkhujaev. 2016. Effects of white wash coating agent on the growth of strawberry seedlings in plastic greenhouses. Protected Hort. and
Plant Factory, 25: 249-254. (in Korean)

Li, H., D. Jiang, B. Woolenweber, T. Dai, and W. Cao. 2010. Effects of shading on morphology, physiology and grain yield of winter wheat. Eur. J. Agron. 33: 267-275.

McCree K.J. 1966. A solarimeter for measuring photosynthetically active radiation. Agric Meteorol. 3:353-366.

McCree K.J. 1972. Test of current definitions on photosynthetically active radiation. Agric Meteorol 10:443-453.

Mori, K., N. Goto-Yamamoto, M. Kitayama, and K. Hashizume. 2007. Loss of anthocyanins in red-wine grape under high temperature. J. Exp. Bot. 58:1035-1945.

Mori, K., S. Sugaya, and H. Gemma. 2005. Decreased anthocyanin biosynthesis in grape berries grown under elevated night temperature condition. Sci. Hortic. 105:319-330.

Park, C.Y., Y.E. Choi, Y.A. Kwon, J.I. Kwon, and H.S. Lee. 2013. Studies on changes and future projections of subtropical climate zones and extreme temperature events over South Korea using high resolution climate change scenario based on PRIDE model. Journal of the Korean Association of Regional Geographers 19:600-614. (in Korean)

Perez, J. and W.M. Kliewer. 1990. Effect of shading on bud necrosis and bud fruitfulness of Thompson Seedless grapevines. Am. J. Enol. Vitic 41:168-175.

Pillet, J., A. Egert, P. Pieri, F. Lecourieux, C. Kappel, J. Charon, E. Gomes, F. Keller, S. Delrot, and D. Lecourieux. 2012. VvGOLS1 and VvHsfA2 are involved in the heat stress responses in grapevine berries. Plant Cell Physiol. 53:1776-1792.

RDA. 2018. Cultural practices for produce grape. Guideline for agricultural technology 12. Rural Development Administration, Jeonju-si, Jeollabuk-do, Republic of Korea.

Smart, R.E. and T.R. Sinclair. 1976. Solar heating of grape berries and other spherical fruit. Agric. Meterorol. 17:241259.

Spayd, S.E., J.M. Tarara. D.L. Mee, and J.C. Ferguson. 2002. Separation of sunlight and temperature effects on the composition of Vitis vinifera cv. Merlot berries. Am. J. Enol. Vitic. 53:171-182.

Tarara, J.M., J. Lee, S.E. Spayd, and C.F. Scagel. 2008. Berry temperature and solar radiation alter acylation, proportion and concentration of anthocyanin in Merlot grapes. Am. J. Enol. Vitic. 59:235-247. 